\title{
Research on College Students' English Learning Based on Network Language Differences between Chinese and English
}

\author{
Jun Liu \\ College of Foreign Studies, Suzhou University, \\ Suzhou city, Anhui province, 234000, China \\ liuhuang503@sohu.com
}

\begin{abstract}
The rapid development of network brings new opportunities for online education, the network language gradually become a new hot spot. Modern information technology provides infinite possibility for the classroom teaching, in this paper, we focus on the motivation of college students to use the network language, and hope to provide scientific and effective measuring tool for the related research of network language. The results showed that under the significance level of 0.05, grade and the often use network language has significant influence to expressing strategy, junior student are more inclined to use the internet language. At the same time, there is no difference in gender and specialty of College Students' network language; this shows that gender differences are gradually weakened in the using of network language. On this basis, we put forward relevant suggestions.
\end{abstract}

Keywords: Network Language, English Learning, Network teaching, College Student

\section{Introduction}

With the development of society and the rapid development of network technology, the Internet has become an indispensable part of people's lives. The development of the Internet has deeply influenced every aspect of people's life. The most notable is the influence of the language. Network language emerges as the times require, and has gradually been concerned by the scholars and experts, and even some linguists predict that a new subject, cyber linguistics is about to be born [1]. In recent years, the discussion and research of network language has gradually become a new hotspot. And the network chat language is the fastest part of the network language. Therefore, it is of great significance to study the language of the Internet. The complexity of the modern information technology, for the optimization of classroom teaching provides infinite possibility; also for classroom teaching give full play too actually practice characteristics provide the technical guarantee[2]. The development and progress of information technology will make the classroom activities of every step, step, and the elements are vivid and closely reflect the autonomy, experience, openness, creativity of practical characteristics. Secondly, diversified and varied teaching theory provides a theoretical guarantee for foreign language teaching in Colleges and universities. In recent years, the foreign advanced teaching ideas and ideas which are represented by humanism and constructivism have been playing a supporting role in the reform of foreign language teaching, which brings the vitality and vigor to the teaching of foreign languages.

Under the guidance of constructivist learning theory, autonomous learning emphasizes the cultivation of individual learning and language communicative competence, while paying attention to the cultivation of students' social cultural competence, discourse competence and strategic ability[3]. The Ministry of education for College English teaching reform, put forward based on computer and classroom teaching mode of College 
English multimedia. On the new teaching model are two aspects: classroom teaching and autonomous learning computer. Classroom refers to the teachers and students in direct contact, face to face communication teaching and autonomous learning of computer is refers to the learners through the computer network of autonomous learning, autonomous learning. This kind of autonomous learning mode means that the computer is no longer an auxiliary role, but the leading role in the teaching[4]. In the process of the implementation of the pilot colleges and universities, the teaching reform mode has different characteristics and conditions, but the real implementation of the reform mode of higher education tends to be the same. Most colleges and universities in the teaching reform mode, the foreign language teaching resources and teaching materials supporting the formation of the teaching mode of system, digital and network, the construction and university English teaching system reform to adapt to college English Autonomous Learning Center and independent learning website, set up teaching resources, teaching management, teaching documents, online reading, online testing, English Teaching Forum and the exchange of teachers and students, to provide students with high efficiency and interactive learning, communication and communication space, create a good English learning environment.

\section{Literature Review}

\subsection{Network Language}

According to the understanding of the academic community, the network language has a wide range of different understanding. Broad sense refers to the use of various forms of language in the field of network communication, including two major categories: first, the Internet related professional terms and special terms, such as broadband, domain name, mouse, virus, browser and Internet users, Internet cafes, hackers, virtual space, information superhighway, two are Internet users in chat rooms and Internet forums on the internet[5-6]. Narrow understanding mainly refers to the latter. And Internet related professional terms and special terms, although the proportion is very large, but this part of the expression will not cause the general network communication in the dispute, even if there are mainly limited to technical or academic areas; and for the general Internet users in the form and content of communication between the situation is a lot of controversy. Based on this, this paper takes a narrow understanding of network language. The emergence and use of network language has been accompanied by a variety of disputes. In favor of the person, who has the. In linguistics, it is mainly based on the combination of language specification and its influence on language teaching and language teaching[7]. The main reason for the specific communication is the embodiment of the spirit of the times, the needs of the new media, the necessity of the development of new media, the Internet culture, the Internet culture. It is a kind of new style. It is a new form of Chinese language.

The main reasons are: the popularity of the Internet will have a negative impact on the Chinese and Chinese, causing the crisis of the mother tongue, the network language is not civilized phenomenon seriously, which affects the language and culture level of the students and the culture and moral education. Therefore, we need to start a Chinese defense war; strengthen the supervision of network language, at least let the network language in the network; through the means of legislation to regulate and restrict the use of network language. Of course, this dichotomy is sometimes not entirely in place, there is a place where there is a cross[8]. If those who approve of the network language also see the negative impact of the network language communication, the people who oppose the network language also see some of the value of the network expression. If you think from the positive aspect, the value of network language should be recognized in two aspects: the nature of communication and the academic significance. 


\subsection{Value of Network Language}

In the description of the network language, the first need to be clear that the need to meet the needs of the network and whether to enter the daily language communication is the two problems, both for the language of communication services, but in different levels of communication system. That is to say, the language value of the network language can be divided into two levels: what is the network communication, which provides the daily language communication [9-10]. But many critics did not recognize the difference, often both confuse, even thought that the latter should be the main value of network language, which is not appropriate. This is secondary. Therefore, to explore the language value of network language also need to adapt to the needs of the network and the daily language of the impact of the two aspects of the understanding of the[11]. That is to say, when a new phenomenon, we must first understand from it on communication with what the language value, so as to make their evaluation has alongside. On the large side, the contribution to the communication is mainly reflected in three aspects: to provide new language elements and language rules; to adjust some of the existing components and rules; to promote the wide use of certain expressions. Below we classify the specific instructions, the use of the use case to the network of words.

1) Vocabulary: gradually providing the basic vocabulary for the network communication, which is the most striking of the network language system? At the same time, with the deepening of network communication and daily communication, a lot of words have been infiltrated into daily communication. Not all the new words in the network, there are many actually new or not, said the old and new. Disputed is the daily communication has a word, and on the network and another neologism, and ways of making words often in everyday language is not commonly used, such as Banzhu refers to the moderator. This forms a distinctive way of expression in the network formation[12].

2) The semantic aspect: both words daily network has given new meanings, extended semantic network. A very important aspect of the semantic network expression is the old word meaning. Some directly from daily language borrowed form and meaning through the expansion of metaphor, metonymy and applied in network communication, such as post, irrigation, diving. Some use, according to Lenovo and refactoring semantic relations, such as dinosaurs, frog[13]. Such as "dinosaur" refers to the ugly, almost for "dragon" on behalf of men, dinosaur old morphology provides researchers, female and ugly. "Jellyfish" refers to the female irrigation madman. Of course, some just don't make use of deconstructive solutions on the literal meaning, such as "Narcissus" refers to irrigation, irrigation madman sin. This is related to the analysis of the above mentioned. This is a kind of way of Chinese word meaning development, which is caused by the re combination of the morpheme and the meaning.

3) Lexical and syntactic aspects: some of the new network of lexical forms, the change in some form of lexical form. The language unit of network language is still the structure of everyday language, even the most network style of Martian text is also so, basically is on the terms of the use of non Chinese characters in the form of a variety of forms, and the combination of the relationship between the numbers of words is not much change. Therefore, the network language basically can be translated into a word daily expression. This is a clear manifestation of the network language, said the new not new. As a new form of expression, it is bound to take a number of new means of expression. Type start-up, a lot to do with language expression embezzle and transformation related, which is a network of expression assortment effect. Such as in English, generally used as prepositions and adverbs, in informal occasions can 
be used as adjectives, but only to do the modification, when referring to the current popular, follow or catch the trend.

\subsection{Network Teaching}

The so-called network foreign language teaching resources, which includes all the familiar learning website and network courseware, also includes other learning materials which can be used in foreign language learning. They are characterized by computer technology, the network teaching content of electronic, personalized and multimedia, which will help learners and teaching content. With the increasing maturity of the network technology, College English teaching model based on campus network and Internet has been popularized in various colleges and universities. The computer network teaching mode emphasizes the individualized teaching and independent learning, students can through the campus network in the learning system, according to their own learning style, choose their own learning content, to achieve the best learning effect. So the study of autonomous learning and online learning becomes more important, especially in the network environment. College English classroom teaching under the network environment has been developed as a teaching model of College English teaching reform in the new century. However, due to the lack of students' autonomous learning ability, the lack of students' independent learning ability, the lack of new technology, the lack of information literacy of teachers, and the requirements of teaching practice and information technology, the paper puts forward a new topic: from theory and practice to study the causes and Strategies of College English classroom teaching.

\section{Research Design and Variable}

\subsection{Multimedia Assisted English Teaching}

Computer aided foreign language teaching emphasizes that teachers use some of the functions of the computer to improve teaching methods, improve teaching effect, the computer is only a kind of auxiliary tool in foreign language teaching. Computer aided teaching began in the continuous upgrading of educational technology, the birth of the concept of educational technology at the beginning of this century, slide, records and silent film technology early at the beginning of the 20th century began was used to auxiliary teaching, radio, film, tape recorders and television has started in the teaching application. At that time, the center of the teaching theory research is teaching mass and the sound - light - electric technology has enhanced the teaching information. Foreign language teaching in the concept of "audio-visual" is the last half a century, the computer began to assist foreign language teaching is probably in the 50's in twentieth Century. Behaviorist (CALL) is the computer aided language teaching in the last century, and it is applied in the teaching of computer aided language teaching in the course of computer aided language teaching in the last century. In 70, the microcomputer, satellite broadcasting and laser disc teaching etc.. The computer aided language teaching in this period is based on the theory of the behavior of the learning, and emphasizes the use of the special design of the computer program to carry out repeated language training and practice.

Interactive computer aided language teaching emerged in the last century 70 and 80 's, artificial intelligence in the 80 's to achieve the machine thinking and highly human. The interactive computer aided language teaching stage has abandoned the theory and teaching method of the behavior, and emphasized the creative learning process from "discovery" and "expression" to "development" by using computer technology. The use of personal computer technology has become a prominent feature of this stage, and the media technology has broadened the access to information. During this period, the computer as a modern teaching media to enter the university English classroom, and even 
beyond the traditional teaching media Assisted College English teaching function, computer, tape, radio, television, VCD, DVD, and so become an important teaching resources. College English class teaching begins to take the students as the center of the teaching structure, pay attention to the new and old knowledge of the nonlinear structure arrangement and multimedia combination. The traditional voice room of the colleges and universities is gradually replaced by the computer multimedia voice room. The construction of the multimedia classroom makes the function of College English classroom teaching greatly enhanced. The teaching mode of College English Teaching in China at this time has gradually shifted from the closed, one-way knowledge and skills to open and multi direction, showing a trend of diversification. Teaching environment also presents the characteristics of openness, interaction, cooperation, diversity and so on; the students gradually have the opportunity to learn English, such as the multimedia teaching CD-ROM and other resources, improve the ability of English application

\subsection{Variables and Sample Statistics}

From the psychological point of view, the research of network language mostly stays in the level of psychological attribution, psychological effects and the analysis of the mentality of the network language. The reason for the use of network language is mostly confined to the development of science and technology and social development, and other factors, such as hacker language, there is still a lot of research space in the depth and breadth of research. In this paper, we focus on the motivation of college students to use the network language, and prepare students to use the network language. The evaluation of College Students' network language use motivation is accomplished by self compiled questionnaire and questionnaire survey. Using semi open questionnaire and expert evaluation method, a total of 2500 college students were selected as semi open questionnaire. The use of network platform to the majority of social groups using the network language, to take the form of network chat or electronic mail and recycling of the questionnaire, a total of 1960 valid questionnaires were returned. The basic data of the questionnaire are shown in Table 1, through the analysis of the forecast results and the analysis of the results, the scale of the students' network language use motivation is concluded, as shown in Table 2.

Table 1. Sample Statistics Analysis

\begin{tabular}{|c|c|c|c|}
\hline Factor & Number & Number & Percent \\
\hline \multirow{2}{*}{ Gender } & Male & 916 & 46.73 \\
\cline { 2 - 4 } & Female & 1044 & 53.26 \\
\hline \multirow{3}{*}{ Grade } & Grade 1 & 834 & 42.55 \\
\cline { 2 - 4 } & Grade 2 & 917 & 46.78 \\
\cline { 2 - 4 } & Grade 3 & 709 & 36.17 \\
\hline \multirow{3}{*}{ Professional } & Language & 375 & 19.13 \\
\cline { 2 - 4 } & Computer & 263 & 13.41 \\
\cline { 2 - 4 } & Other & 1022 & 52.14 \\
\hline \multirow{2}{*}{$\begin{array}{c}\text { using network } \\
\text { language }\end{array}$} & Often & 670 & 34.18 \\
\cline { 2 - 4 } & no & 275 & 14.03 \\
\cline { 2 - 4 } & Occasionally & 715 & 36.47 \\
\hline
\end{tabular}

Table 2. Factor Analysis using Network Language

\begin{tabular}{|c|c|c|c|c|}
\hline Motivation & Number (n) & Percent (\%) & Male (\%) & Female (\%) \\
\hline Game & 723 & 18.2 & 79.6 & 20.4 \\
\hline Internet chat & 1689 & 42.5 & 46.3 & 53.6 \\
\hline Daily & 433 & 10.9 & 52.3 & 47.7 \\
\hline
\end{tabular}




\begin{tabular}{|c|c|c|c|c|}
\hline conversation & & & & \\
\hline $\begin{array}{c}\text { Mobile phone } \\
\text { text messages }\end{array}$ & 610 & 15.3 & 35.0 & 65.0 \\
\hline Writing & 168 & 4.2 & 42.5 & 57.5 \\
\hline Curse & 193 & 4.8 & 78.6 & 21.4 \\
\hline Other times & 154 & 3.8 & 61.2 & 38.8 \\
\hline
\end{tabular}

\section{Empirical Analysis}

\subsection{Exploratory Factor Analysis}

The coefficient of KMO is 0.878 , the partial correlation is weak, and it is suitable for factor analysis. The value of Bartlett sphere test is 2400.132, and the value is 0 , which is suitable for exploratory factor analysis. Principal component analysis (PC) and oblique rotation factor analysis were conducted on the questionnaire data, as shown in Figure 1. The analysis results show that there are 5 factors of the characteristic values of 1 , and the results show that the network language uses the motivation structure to retain 5 factors.

\section{Table 3. The Result of KMO Statistical Test}

\begin{tabular}{|l|c|c|}
\hline \multicolumn{2}{|c|}{ Kaiser-Meyer-Olkin } & .878 \\
\hline \multirow{3}{*}{ Bartlett test } & Approximate chi-square & 2400.132 \\
\cline { 2 - 3 } & $\mathrm{df}$ & 276 \\
\cline { 2 - 3 } & Sig. & 0.000 \\
\hline
\end{tabular}

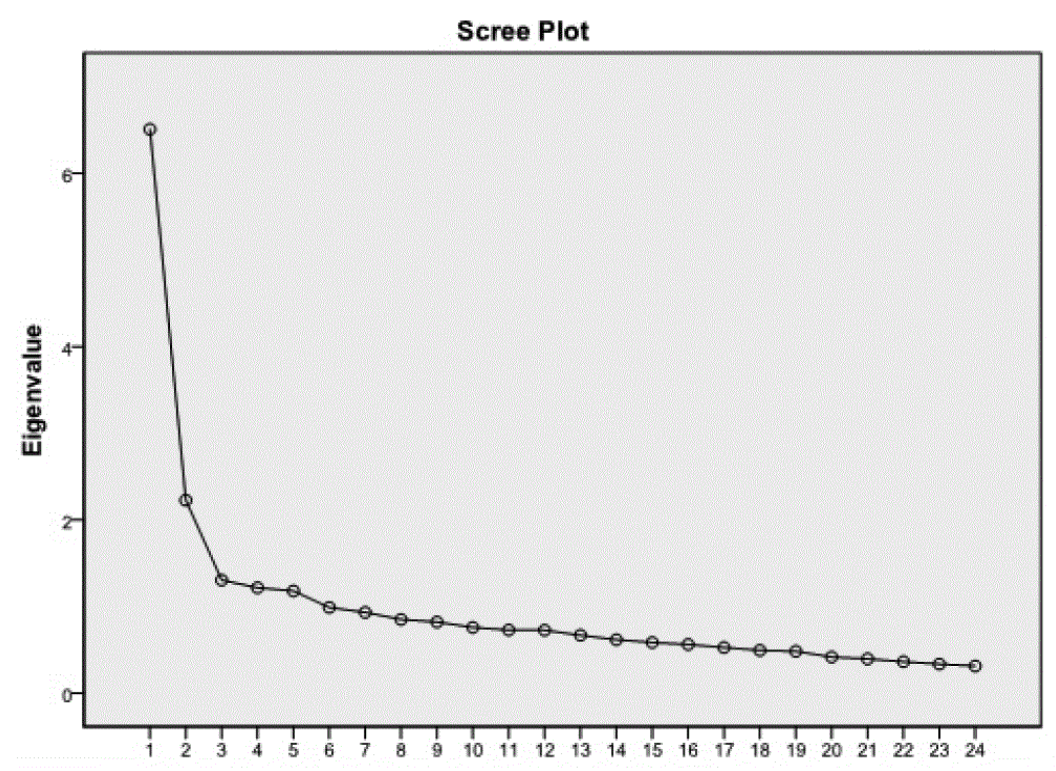

Figure 1. Steep Rock Slope of Exploratory Factor Analysis

\subsection{Reliability Test}

The five factors cannot be aggregated into other dimensions. In addition, it is found that there are 1 factors which are: factor 1 , which is named as: factor 2 , factor 3 , factor 4 , factor, factor, factor 5, and factor 5. Through the analysis of SPSS, the internal consistency coefficient $0.773-0.878$, the internal consistency coefficient was 0.825 , the 
split half reliability was 0.873 , and these results showed that the questionnaire had good reliability.

Table 4.Reliability Analysis of Variable

\begin{tabular}{|c|c|c|}
\hline Variable & Index & $\alpha$ coefficient value \\
\hline \multirow{2}{*}{ Expressing strategy } & Expression appears to be humorous & \multirow{2}{*}{0.878} \\
\cline { 2 - 2 } Escape ownership & Leave a deep impression & \multirow{2}{*}{0.842} \\
\cline { 2 - 2 } Communication needs & Escape from social perspective & \multirow{2}{*}{0.773} \\
\cline { 2 - 2 } Commiduality & Contribute to communication & \multirow{2}{*}{0.825} \\
\hline \multirow{2}{*}{ Cover up } & Conducive to understanding & \multirow{2}{*}{0.825} \\
\cline { 2 - 2 } Randomness & Conceal oneself mood & \multirow{2}{*}{0.869} \\
\cline { 2 - 2 } & Free expression & \multicolumn{2}{|c}{} \\
\hline
\end{tabular}

\subsection{Results and Analysis}

Using the college students' school, gender, grade, specialty as the independent variables, the effect of the interaction on the expression strategy is obvious. The influence of the network language and the use of network language on the total score is two. The results show that there is a significant difference in the amount of net language use. From table 5, there is a significant difference in the grade. As can be seen from table 6, the overall difference is significant, the performance of students in common network language scores are higher than the occasional use of network language and do not often use the network language students, but occasionally the use of network language and the students do not often use the network language is not a significant difference. In expressing strategy, it is obvious that the common network language, the network language and the occasional use of the network language, the students in common network language have the highest score, and the students with no network language have the lowest score.

Table 5. Grade Difference of College Students' Network Language

\begin{tabular}{|c|c|c|c|c|c|c|}
\hline \multirow{2}{*}{ Variable } & \multicolumn{2}{|c|}{ Low grade } & \multicolumn{2}{c|}{ High grade } & \multirow{2}{*}{$\mathrm{F}$} & \multirow{2}{*}{$\mathrm{P}$} \\
\cline { 2 - 5 } & $\mathrm{M}$ & $\mathrm{SD}$ & $\mathrm{M}$ & $\mathrm{SD}$ & & \\
\hline Expressing strategy & 0.076 & 0.998 & -0.049 & 1.001 & 0.430 & 0.513 \\
\hline Escape ownership & -0.078 & 0.930 & 0.050 & 1.042 & 7.484 & 0.007 \\
\hline Communication & -0.134 & 0.965 & 0.086 & 1.015 & 0.855 & 0.356 \\
\hline Cover up & -0.156 & 1.029 & 0.100 & 0.970 & 0.696 & 0.405 \\
\hline Randomness & -0.146 & 0.915 & 0.094 & 1.042 & 1.445 & 0.230 \\
\hline total score & 71.784 & 11.649 & 74.593 & 12.965 & 8.500 & 0.004 \\
\hline
\end{tabular}

Table 6. Differences of College Students' network language

\begin{tabular}{|c|c|c|c|c|c|c|c|c|}
\hline \multirow{2}{*}{ Variable } & \multicolumn{2}{|c|}{ Often } & \multicolumn{2}{c|}{ Occasionally } & \multicolumn{2}{c|}{ never } & \multirow{2}{*}{$\mathrm{F}$} & \multirow{2}{*}{$\mathrm{P}$} \\
\cline { 2 - 9 } & $\mathrm{M}$ & $\mathrm{SD}$ & $\mathrm{M}$ & $\mathrm{SD}$ & $\mathrm{M}$ & $\mathrm{SD}$ & & \\
\hline Expressing strategy & 0.346 & 1.074 & -0.017 & 0.887 & -0.669 & 1.070 & 16.27 & 0.00 \\
\hline Escape ownership & 0.170 & 1.067 & -0.045 & 1.008 & -0.132 & 0.745 & 1.50 & 0.22 \\
\hline Communication & 0.153 & 0.913 & -0.054 & 0.981 & -0.045 & 1.248 & 0.99 & 0.37 \\
\hline Cover up & 0.157 & 1.131 & -0.081 & 0.932 & 0.089 & 1.024 & 1.24 & 0.29 \\
\hline Randomness & -0.175 & 0.961 & 0.052 & 0.940 & 0.105 & 1.327 & 2.86 & 0.05 \\
\hline total score & 78.239 & 13.570 & 72.526 & 11.802 & 68.275 & 10.811 & 9.87 & 0.00 \\
\hline
\end{tabular}




\section{Conclusion}

This study through college students to carry out an effective questionnaire survey, to a large extent, the current understanding of the development of the network language use motivation of College students. From the overall level, college students' network language use is more frequent, but there are still various aspects of the difference. Gender, age, grade, school nature, etc.. In this study, we explore the differences of College Students' network language using the differences between College Students' grade, gender, professional and whether they are commonly used in network language. This shows that in the network communication language neutral differences are gradually weakened, different from the real society women will hide a lot of personal information, in the network log, the men and women in the account of personal information is not big. There is no difference in the network language, which may be in the network communication is not too many computer professional terms of communication, but on life, emotion and other aspects of communication, its professional characteristics did not affect the way the network communication. The motivation of College Students' network language use is different in grade, which is expressed as grade students' score higher than grade two students. The reason may be: on the one hand, college students just after school, is attracted by the network such as the new things, and because of the free time, so the first grade students to online almost become the main activities of College Students' leisure time, in order to better carry out network communication, network language use motivation. And from high school into the University, because of living space, life content changes, need to adjust themselves to adapt to the new learning, living environment, in the adaptation process will generally experience loneliness, loss and even self-esteem, they need to find ways to release or relieve pressure, seek temporary psychological comfort, or to vent their negative emotions. Because of anonymity, convenience and escape from reality, the Internet provides a good place for the new students and the network language as a new thing also attracts the young people. The students of grade two gradually reduce the network and network language.

College students often use the network language or not to have a significant difference in motivation, which is higher than the students who use the network language. But there is no significant difference between the students who use the Internet language and the network language. This may be the occasional use of network language students and do not often use the network language of the students are not used to form a habit, in the network communication or communication performance is not a big difference. In expressing strategy, it is obvious that the common network language, the network language and the occasional use of network language, the students in common network language have the highest score in the expression strategy. This may be a contact network language is the more frequent students to their familiarity and habits greatly increased, so that in the network communication or communication performance more strongly motivated.

\section{References}

[1] C.Krstev, and A.Trtovac, "Teaching Multimedia Documents to LIS Students", The Journal of Academic Librarianship, vol.40, no.2, (2014), pp.152-162.

[2] M. Armenteros, and S.Liaw, "Surveying FIFA instructors' behavioral intention toward the Multimedia Teaching Materials “,Computers \& Education, vol.61, (2013), pp.91-104.

[3] M.Hu, S.Xu, "Research of Multimedia Teaching on Principles of Management",IERI Procedia, vol.2, (2012), pp.666-670 .

[4] S.Jian-hua, L.hong, "Explore the Effective Use of Multimedia Technology in College Physics Teaching",Energy Procedia, vol.17, (2012), pp.1897-1900.

[5] W.Dai, L.Fan, "Discussion about the Pros and Cons and Recommendations for Multimedia Teaching in Local Vocational Schools",Physics Procedia, vol.33, (2012), pp.1144-1148.

[6] C. wei, Y.tao, "Application of Multimedia-Aided Project-Teaching Mode in Cultural Education", IERI Procedia, vol.2, (2012), pp.538-542. 
[7] C.Zhang, X.Chen, "Use of Multimedia in Gross Infective Pathogen Experimental Teaching”, Procedia Engineering, vol.37, (2012), pp.64-67.

[8] H.wanliang, L.Dan, "Experimental Research on the Multimedia CAI Courseware in the University Tennis Teaching",Procedia Engineering, vol.23, (2011),pp.339-344.

[9] A.K.Kim and J.Davies, "A teacher's perspective on student centred learning: Towards the development of best practice in an undergraduate tourism course", Journal of Hospitality, Leisure, Sport \& Tourism Education, vol.25,(2014),pp. 6-14.

[10] Y.Huang and S.Backman, "Experiencing student learning and tourism training in a 3D virtual world: An exploratory study”,Journal of Hospitality, Leisure, Sport \& Tourism Education, vol.13, (2013), pp.190201.

[11] S.Jadhav, R.Yeravdekar, "Cross-border Healthcare Access in South Asian Countries: Learnings for Sustainable Healthcare Tourism in India",Procedia - Social and Behavioral Sciences, vol.157, (2014), pp.109-117.

[12] M.Sigala, "Investigating the role and impact of geovisualisation and geocollaborative portals on collaborative e-learning in tourism education",Journal of Hospitality, Leisure, Sport \& Tourism Education, vol.11, (2012), pp.50-66.

[13] H.Janta and P.Lugosi, "Migrant networks, language learning and tourism employment", Tourism Management, vol.33, no. 2,(2012), pp.431-439. 
International Journal of Security and Its Applications

Vol.9, No.11 (2015) 